Prepared in cooperation with Gwinnett County, Georgia

\title{
Flood-Inundation Maps for Suwanee Creek from the Confluence of Ivy Creek to the Noblin Ridge Drive Bridge, Gwinnett County, Georgia
}

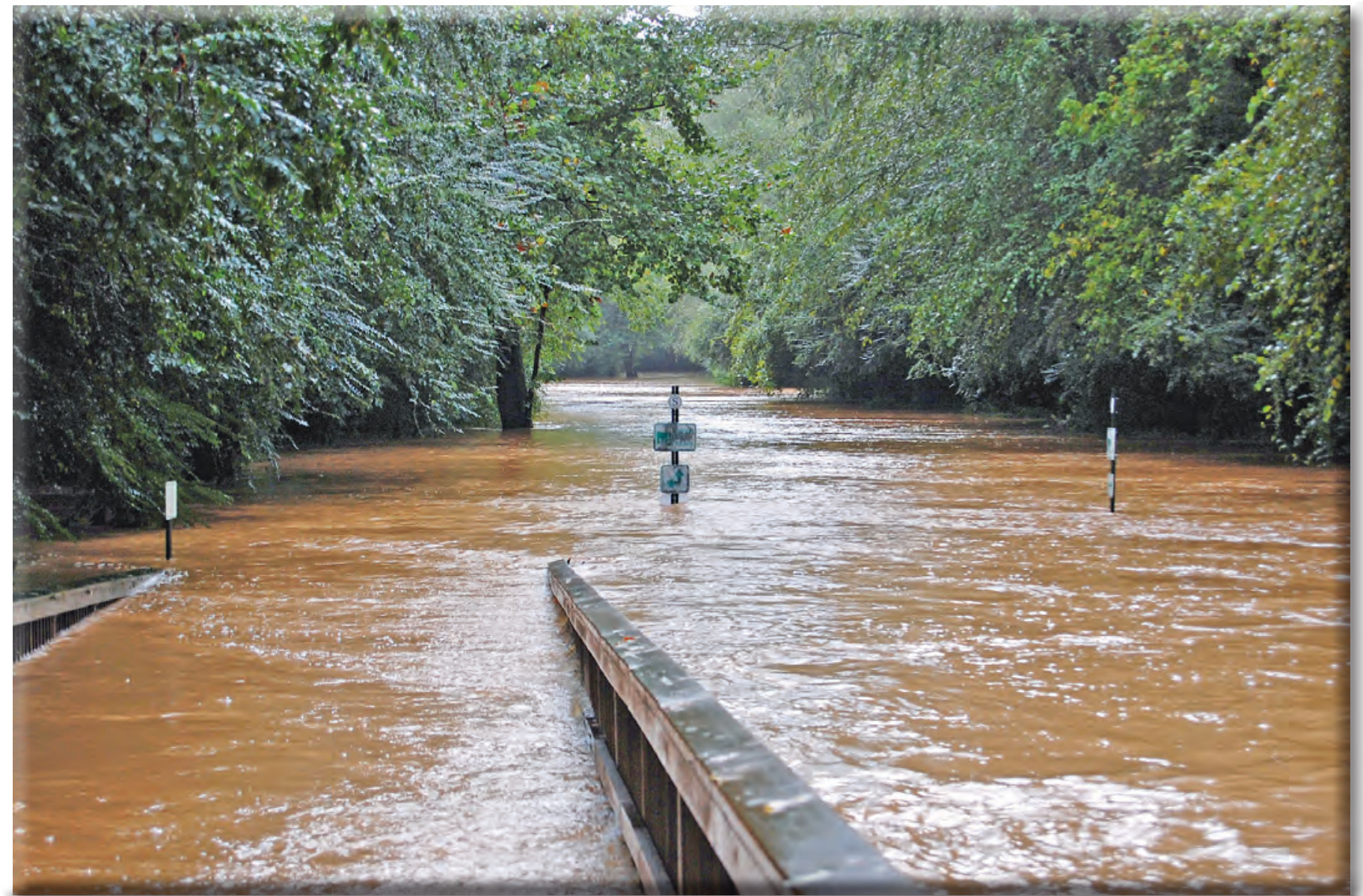

Pamphlet to accompany

Scientific Investigations Map 3226 
Cover. Suwanee Creek flooding greenway trail, September 20, 2009 (photograph from City of Suwanee, Georgia). 


\section{Flood-Inundation Maps for Suwanee Creek from the Confluence of lvy Creek to the Noblin Ridge Drive Bridge, Gwinnett County, Georgia}

By Jonathan W. Musser

Prepared in cooperation with Gwinnett County, Georgia

Pamphlet to accompany

Scientific Investigations Map 3226 


\section{U.S. Department of the Interior \\ KEN SALAZAR, Secretary \\ U.S. Geological Survey \\ Marcia K. McNutt, Director}

\section{U.S. Geological Survey, Reston, Virginia: 2012}

For more information on the USGS - the Federal source for science about the Earth, its natural and living resources, natural hazards, and the environment, visit http://www.usgs.gov or call 1-888-ASK-USGS

For an overview of USGS information products, including maps, imagery, and publications, visit $h$ ttp://www.usgs.gov/pubprod

To order this and other USGS information products, visit http://store.usgs.gov

Any use of trade, product, or firm names is for descriptive purposes only and does not imply endorsement by the U.S. Government.

Although this report is in the public domain, permission must be secured from the individual copyright owners to reproduce any copyrighted materials contained within this report.

Suggested citation:

Musser, J.W., 2012, Flood-inundation maps for Suwanee Creek from the confluence of Ivy Creek to the Noblin Ridge Drive bridge, Gwinnett County, Georgia: U.S. Geological Survey Scientific Investigations Map 3226, 8 p. pamphlet, 19 sheets; available online at http://pubs.usgs.gov/sim/3226/. 


\section{Contents}

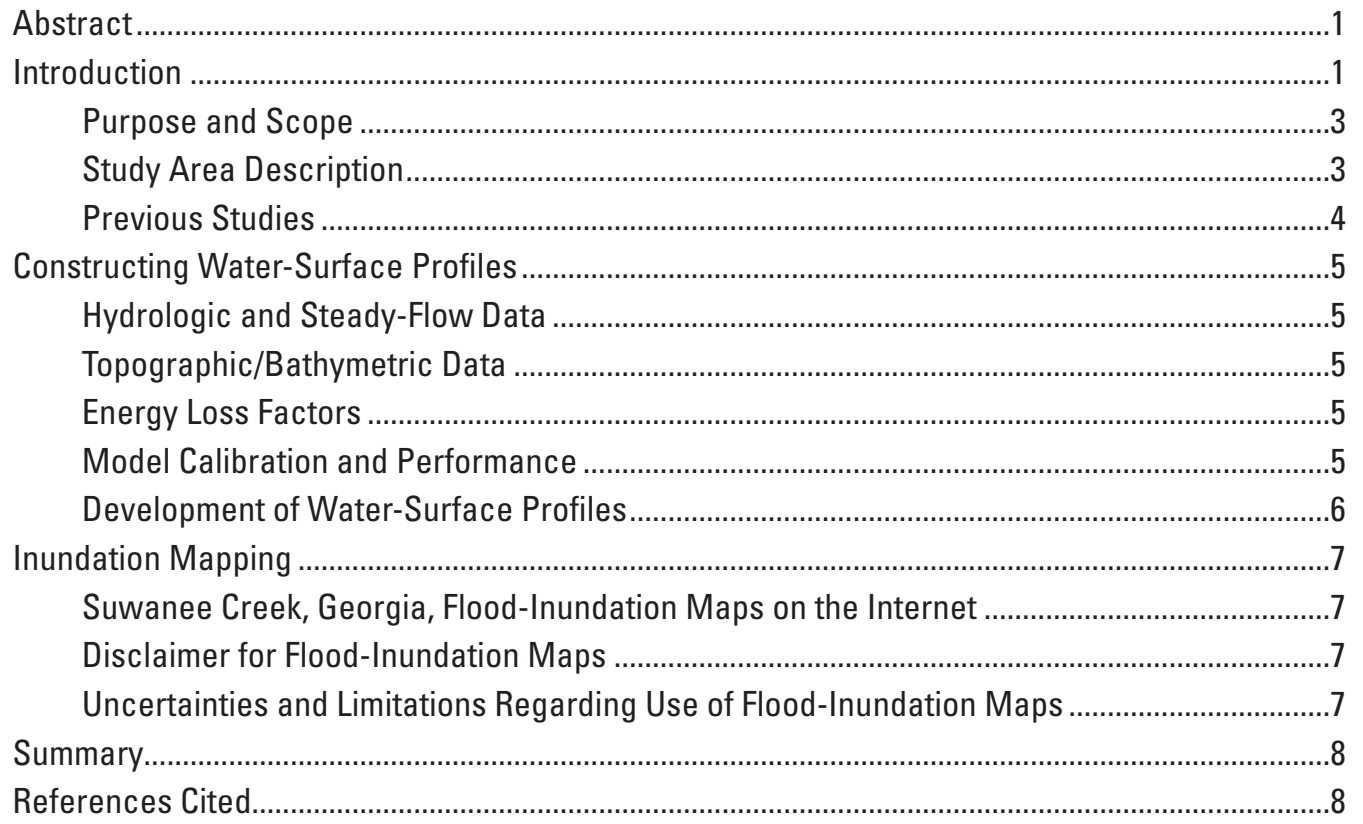

\section{Figures}

1. Map showing location of study reach for Suwanee Creek and location of U.S. Geological Survey streamgage and National Weather Service forecast site ...................2

2. Map showing Suwanee Creek bridge crossings, model extent, and direction of

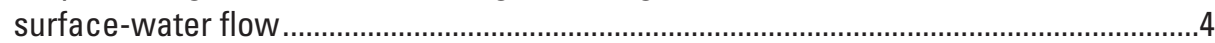

\section{Tables}

1. Site information for the U.S. Geological Survey streamgage in the Suwanee Creek basin at Suwanee, Georgia

2. Comparison of hydraulic-model output and water-surface elevations at the Suwanee Creek at Suwanee, Georgia, streamgage.

3. Stages (and water-surface elevations) with corresponding discharge estimates for selected simulated water-surface profiles at selected locations for the Suwanee Creek at Suwanee, Georgia, streamgage.

4. Stream stages (and water-surface elevations) at the Suwanee Creek at Suwanee, Georgia, streamgage, with reference to corresponding map-sheet numbers in this report. 


\section{Sheets (Each sheet has individual pdf and jpg files available for download. For links, see http://pubs.usgs.gov/sim/3226/.)}

1-19. Maps showing flood-inundation of Suwanee Creek in Gwinnett County, Georgia, corresponding to a gage height and an elevation (NAVD 88) as listed below at U.S. Geological Survey streamgage Suwanee Creek at Suwanee, Georgia (02334885) -

1. Gage height of 7.0 feet and an elevation of 916.9 feet

2. Gage height of 7.5 feet and an elevation of 917.4 feet

3. Gage height of 8.0 feet and an elevation of 917.9 feet

4. Gage height of 8.5 feet and an elevation of 918.4 feet

5. Gage height of 9.0 feet and an elevation of 918.9 feet

6. Gage height of 9.5 feet and an elevation of 919.4 feet

7. Gage height of 10.0 feet and an elevation of 919.9 feet

8. Gage height of 10.5 feet and an elevation of 920.4 feet

9. Gage height of 11.0 feet and an elevation of 920.9 feet

10. Gage height of 11.5 feet and an elevation of 921.4 feet

11. Gage height of 12.0 feet and an elevation of 921.9 feet

12. Gage height of 12.5 feet and an elevation of 922.4 feet

13. Gage height of 13.0 feet and an elevation of 922.9 feet

14. Gage height of 13.5 feet and an elevation of 923.4 feet

15. Gage height of 14.0 feet and an elevation of 923.9 feet

16. Gage height of 14.5 feet and an elevation of 924.4 feet

17. Gage height of 15.0 feet and an elevation of 924.9 feet

18. Gage height of 15.5 feet and an elevation of 925.4 feet

19. Gage height of 16.0 feet and an elevation of 925.9 feet 


\section{Conversion Factors and Datums}

\begin{tabular}{lcl}
\hline \multicolumn{1}{c}{ Multiply } & By & \multicolumn{1}{c}{ To obtain } \\
\hline inch & Length & \\
foot $(\mathrm{ft})$ & 25.4 & millimeter $(\mathrm{mm})$ \\
mile $(\mathrm{mi})$ & 0.3048 & meter $(\mathrm{m})$ \\
\hline & 1.609 & kilometer $(\mathrm{km})$ \\
\hline square foot $\left(\mathrm{ft}^{2}\right)$ & Area & square meter $\left(\mathrm{m}^{2}\right)$ \\
square mile $\left(\mathrm{mi}^{2}\right)$ & 0.0929 & square kilometer $\left(\mathrm{km}^{2}\right)$ \\
\hline & 2.590 & \\
\hline cubic foot per second $\left(\mathrm{ft}^{3} / \mathrm{s}\right)$ & Flow rate & cubic meter per second $\left(\mathrm{m}^{3} / \mathrm{s}\right)$ \\
\hline & 0.02832 & meter per kilometer $\left(\mathrm{m} / \mathrm{km}^{2}\right)$ \\
\hline foot per mile $(\mathrm{ft} / \mathrm{mi})$ & Hydraulic gradient & \\
\hline
\end{tabular}

Vertical coordinate information is referenced to the North American Vertical Datum of 1988 (NAVD 88).

Horizontal coordinate information is referenced to the North American Datum of 1983 (NAD 83).

Elevation, as used in this report, refers to the distance above NAVD 88.

Stage, as used in this report, is the elevation of the water surface above an arbitrary datum established at the gage (gage datum).

\section{Acronyms and Additional Abbreviations}

$\begin{array}{ll}\text { AHPS } & \text { Advanced Hydrologic Prediction Service } \\ \text { DFIRM } & \text { Digital Flood Insurance Rate Map } \\ \text { FEMA } & \text { Federal Emergency Management Agency } \\ \text { GIS } & \text { geographic information system } \\ \text { LiDAR } & \text { light detection and ranging } \\ \text { NED } & \text { National Elevation Dataset } \\ \text { NWS } & \text { National Weather Service } \\ \text { RMSE } & \text { root-mean-square error } \\ \text { USGS } & \text { U.S. Geological Survey }\end{array}$

\section{Acknowledgments}

The author wishes to thank Gwinnett County for funding operation and maintenance of streamgages used for this study. Special thanks are given to the National Weather Service for their continued support to the U.S. Geological Survey flood-inundation mapping initiative. 



\title{
Flood-Inundation Maps for Suwanee Creek from the Confluence of Ivy Creek to the Noblin Ridge Drive Bridge, Gwinnett County, Georgia
}

\author{
By Jonathan W. Musser
}

\begin{abstract}
Digital flood-inundation maps for a 6.9-mile reach of Suwanee Creek, from the confluence of Ivy Creek to the Noblin Ridge Drive bridge, were developed by the U.S. Geological Survey (USGS) in cooperation with Gwinnett County, Georgia. The inundation maps, which can be accessed through the USGS Flood Inundation Mapping Science Web site at http://water.usgs.gov/osw/flood_inundation/, depict estimates of the areal extent and depth of flooding corresponding to selected water levels (stages) at the USGS streamgage at Suwanee Creek at Suwanee, Georgia (02334885). Current stage at this USGS streamgage may be obtained at http://waterdata.usgs.gov/ and can be used in conjunction with these maps to estimate near real-time areas of inundation. The National Weather Service (NWS) is incorporating results from this study into the Advanced Hydrologic Prediction Service (AHPS) flood-warning system (http://water.weather.gov/ahps/). The NWS forecasts flood hydrographs at many places that commonly are collocated at USGS streamgages. The forecasted peak-stage information for the USGS streamgage at Suwanee Creek at Suwanee (02334885), available through the AHPS Web site, may be used in conjunction with the maps developed in this study to show predicted areas of flood inundation.

A one-dimensional step-backwater model was developed using the U.S. Army Corps of Engineers HEC-RAS software for Suwanee Creek and was used to compute flood profiles for a 6.9-mile reach of the creek. The model was calibrated using the most current stage-discharge relations at the Suwanee Creek at Suwanee streamgage (02334885). The hydraulic model was then used to determine 19 water-surface profiles for flood stages at the Suwanee Creek streamgage at 0.5 -foot intervals referenced to the streamgage. The profiles ranged from just above bankfull stage (7.0 feet) to approximately 1.7 feet above the highest recorded water level at the streamgage (16.0 feet). The simulated water-surface profiles were then combined with a geographic information system digital elevation model — derived from light detection
\end{abstract}

and ranging (LiDAR) data having a 5.0-foot horizontal resolution - to delineate the area flooded for each 0.5 -foot increment of stream stage.

The availability of these maps, when combined with real-time stage information from USGS streamgages and forecasted stream stage from the NWS, provides emergency management personnel and residents with critical information during flood-response activities, such as evacuations and road closures, as well as for post-flood recovery efforts.

\section{Introduction}

Gwinnett County, Georgia (Ga.), is a suburban community with a population of 805,321 in 2010 (U.S. Census Bureau, 2012; fig. 1). Development on flood plains within the county is varied with a mix of residential, recreational, and commercial structures, and areas of agriculture, grass fields, wetlands, and forest. Suwanee Creek flows through Suwanee, Ga., which is in the northwestern part of Gwinnett County. In September of 2009, Gwinnett County experienced record flooding along Suwanee Creek.

Prior to this study, Gwinnett County and City of Suwanee officials have relied on several information sources (available on the Internet) to make decisions on how best to alert the public and mitigate flood damages along Suwanee Creek. One source of information is the Federal Emergency Management Agency (FEMA) Digital Flood Insurance Rate Map (DFIRM) (Federal Emergency Management Agency, 2011). A second source of information is the U.S. Geological Survey (USGS) streamgage (table 1) - Suwanee Creek at Suwanee, Ga. (02334885) - from which current or historical water levels (stage) can be obtained. Stage is the height of the water surface above an arbitrary datum established at the gage (gage datum). A third source is the National Weather Service (NWS) forecast of peak stage at the USGS Suwanee Creek at Suwanee streamgage (forecast site SWEG1) through the Advanced Hydrologic Prediction Service (AHPS) Web site at http://water.weather.gov/ahps/. 

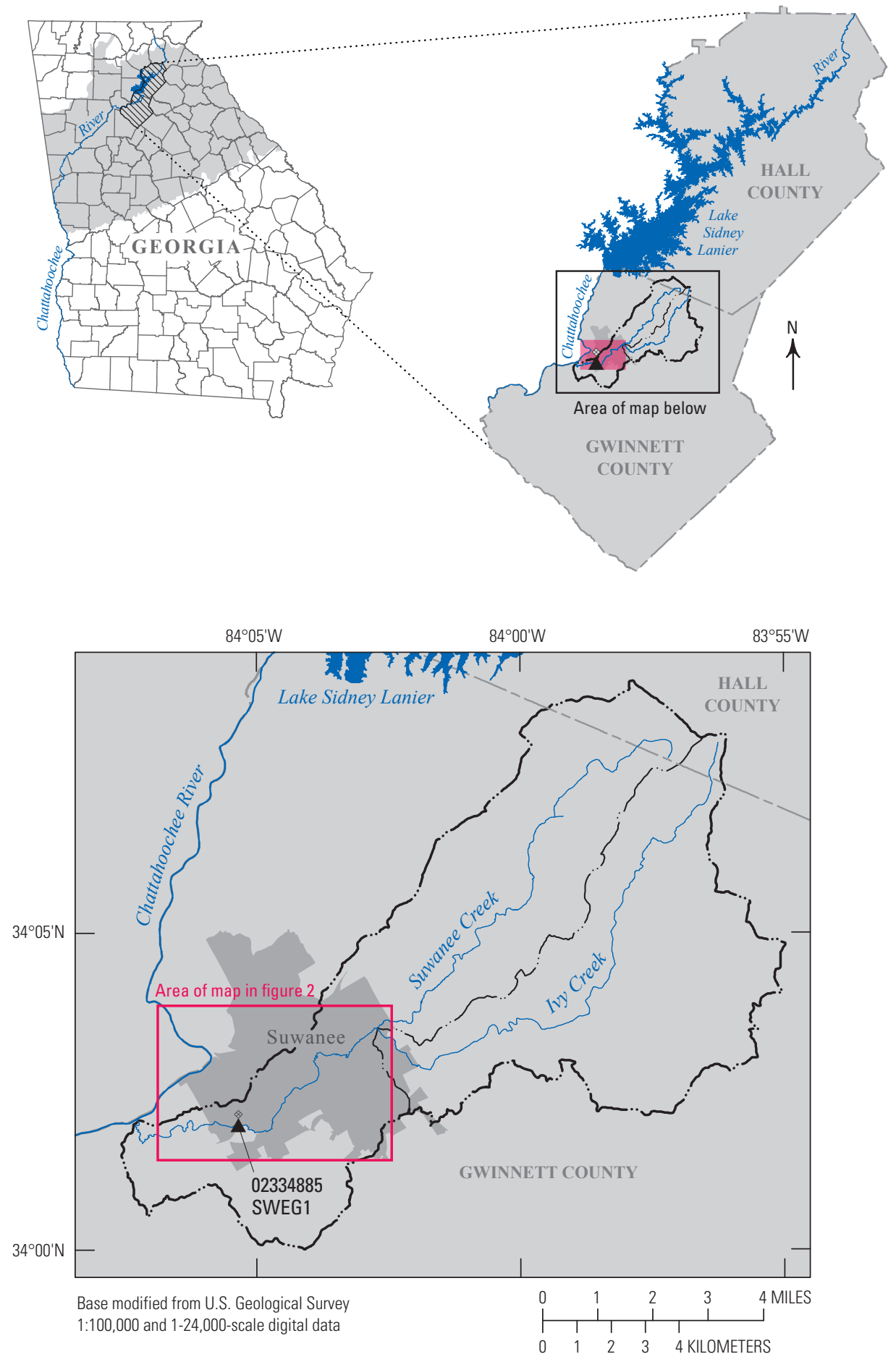

EXPLANATION

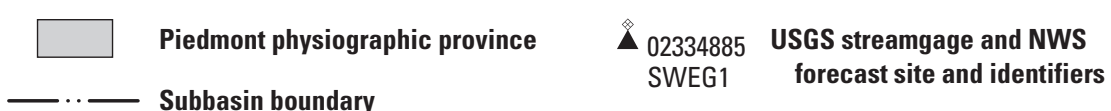

Figure 1. Location of study reach for Suwanee Creek and location of U.S. Geological Survey streamgage and National Weather Service (NWS) forecast site. 
Table 1. Site information for the U.S. Geological Survey streamgage in the Suwanee Creek basin at Suwanee, Georgia.

[USGS, U.S. Geological Survey; Ga., Georgia; ft, foot; current year, year of publication; see fig. 1 for station location]

\begin{tabular}{|c|c|c|c|c|c|c|}
\hline \multirow{2}{*}{ Station name } & \multirow{2}{*}{$\begin{array}{l}\text { USGS } \\
\text { station } \\
\text { number }\end{array}$} & \multirow{2}{*}{$\begin{array}{l}\text { Drainage area } \\
\text { (square miles) }\end{array}$} & Latitude & Longitude & \multirow{2}{*}{$\begin{array}{l}\text { Period of } \\
\text { record }\end{array}$} & \multirow{2}{*}{$\begin{array}{l}\text { Maximum } \\
\text { recorded stage } \\
\text { at gage and date }\end{array}$} \\
\hline & & & \multicolumn{2}{|c|}{ (degrees, minutes, seconds) } & & \\
\hline $\begin{array}{c}\text { Suwanee Creek at } \\
\text { Suwanee, Ga. }\end{array}$ & 02334885 & 47.0 & $34^{\circ} 01^{\prime} 56^{\prime \prime}$ & $84^{\circ} 05^{\prime} 22^{\prime \prime}$ & $\begin{array}{c}1985 \text { to } \\
\text { current year }\end{array}$ & $\begin{array}{c}14.30 \mathrm{ft} \\
\text { Sept. } 21,2009\end{array}$ \\
\hline
\end{tabular}

Although USGS current stage and NWS forecast stage data are particularly useful for residents in the immediate vicinity of a streamgage, the data are of limited use to residents farther upstream or downstream because the water-surface elevation is not constant along the entire stream channel. Also, FEMA and State emergency management mitigation teams or property owners typically lack information related to water depth at locations other than locations near USGS streamgages or NWS flood-forecast points. To help guide the general public in taking individual safety precautions and provide local officials with a tool to help efficiently manage emergency flood operations and flood-mitigation efforts, digital flood-inundation maps for a 6.9-mile (mi) reach of Suwanee Creek were developed by the USGS in cooperation with Gwinnett County, Ga.

\section{Purpose and Scope}

The purpose of this report is to describe the development of a series of estimated flood-inundation maps for Suwanee Creek in Gwinnett County, Ga. The maps and other flood information are available on the USGS Flood Inundation Mapping Science Web site at http://water.usgs.gov/osw/flood_ inundation/ and the previously mentioned NWS AHPS Web site. Internet users can select estimated inundation maps that would be close to (1) current stage at the USGS streamgage at Suwanee (02334885), (2) the NWS forecasted peak stage, or (3) other desired stream stages.

The scope of the study was limited to a 6.9-mi reach of Suwanee Creek from about 440 feet (ft) above the confluence of Suwanee Creek and Ivy Creek to about $930 \mathrm{ft}$ downstream of the Noblin Ridge Drive bridge (fig. 2). Tasks specific to development of the flood-inundation maps were (1) analysis of the flow and stage data collected at one streamgage, Suwanee Creek at Suwanee (02334885) (table 1); (2) collection of topographic data and geometric data (for structures, bridges, and the stream channel) throughout the study reach; (3) determination of energy-loss factors (roughness coefficients) in the stream channel and flood plain; (4) computation of water-surface profiles using the U.S. Army Corps of Engineers HEC-RAS computer program (U.S. Army Corps of Engineers, Hydrologic Engineering Center, 2010); (5) production of estimated flood-inundation maps at various stream stages using the U.S. Army Corps of Engineers HEC-GeoRAS computer program (U.S. Army Corps of Engineers, Hydrologic Engineering Center, 2009) and a geographic information system (GIS); and (6) development of a Web site interface that links to USGS real-time streamgage information and (or) NWS forecasted peak stage to facilitate the display of userselected flood-inundation maps on the Internet.

Methods used generally are cited from previously published reports (Bales and others, 2007; Whitehead and Ostheimer, 2009). If techniques varied substantially from previously documented methods because of local hydrologic conditions or available data, they are described in detail in this report. Maps were produced for water levels referenced to the stage at Suwanee Creek at Suwanee (02334885) and ranged from approximately bankfull $(7.0 \mathrm{ft})$ to above the maximum observed water level at the streamgage (16.0 ft).

\section{Study Area Description}

Suwanee Creek is in northern Georgia in the Piedmont physiographic province (Clark and Zisa, 1976). The drainage area ranges from 39.2 square miles $\left(\mathrm{mi}^{2}\right)$ at the confluence of Ivy Creek to $47.0 \mathrm{mi}^{2}$ at the Suwanee Creek at Suwanee streamgage (02334885) to $50.7 \mathrm{mi}^{2}$ below Noblin Ridge Drive at the downstream extent of the study reach (fig. 2). The headwaters of Suwanee Creek originate in Gwinnett and Hall Counties (fig. 1). Suwanee Creek and its tributaries generally flow southwestward through Gwinnett County until Suwanee Creek joins with the Chattahoochee River. Ivy Creek is the one major tributary that flows into Suwanee Creek. The basin terrain is gently rolling with stream valleys that are fairly deep and narrow and lie 100 to $200 \mathrm{ft}$ below the narrow, rounded stream divides (Clark and Zisa, 1976). The study reach is about $6.9 \mathrm{mi}$ long, with an average channel slope of about 7.2 feet per mile ( $\mathrm{ft} / \mathrm{mi})$. The land that is contiguous to the study reach is mostly classified as developed, with some areas classified as forest. Some large areas of woody wetlands are along Suwanee Creek and its tributaries (Fry and others, 2011). The main channel within the study reach has six major road bridges, two footbridges, and one railroad bridge that cross the channel and the adjacent flood plain. 


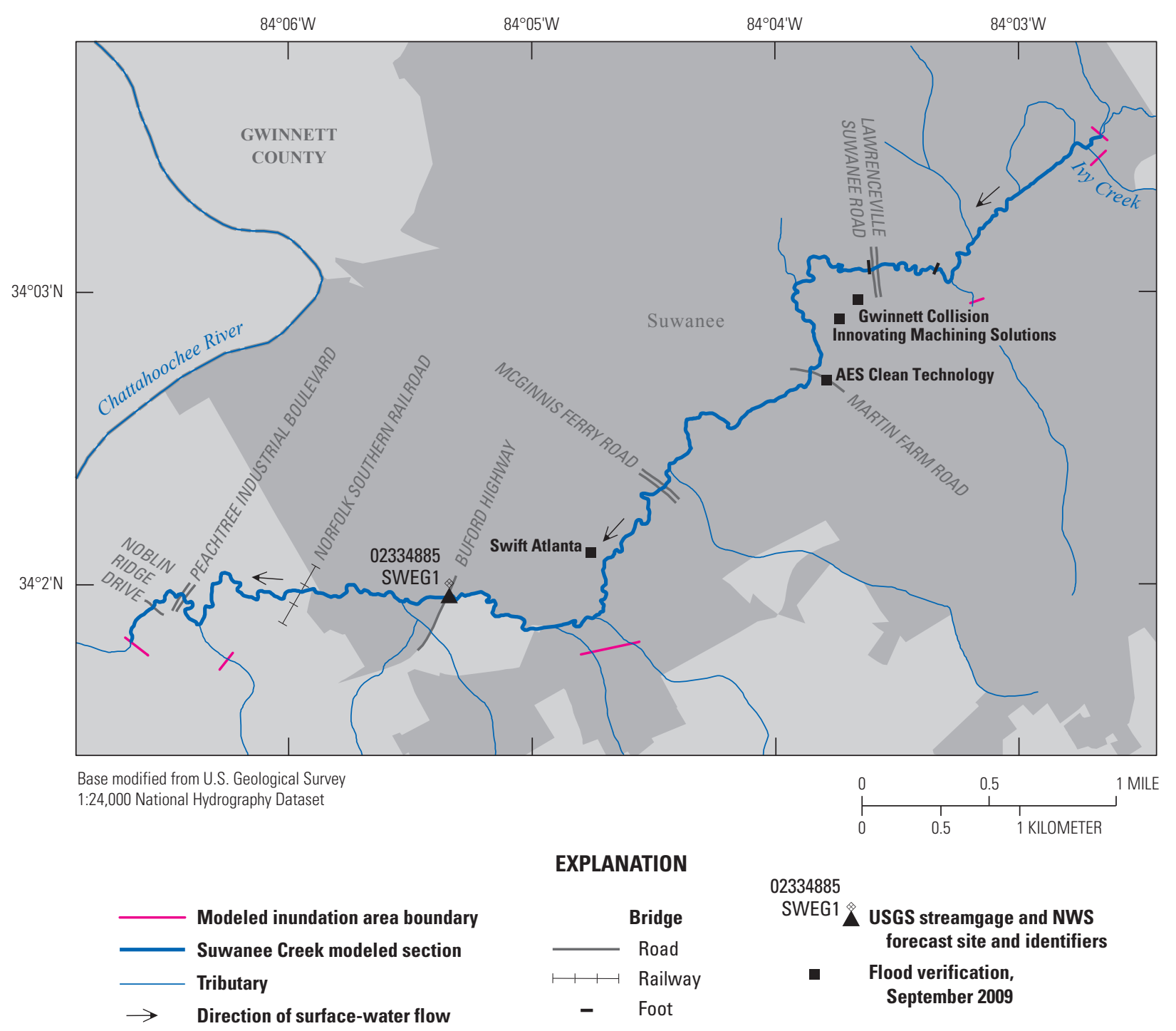

Figure 2. Suwanee Creek bridge crossings, model extent, and direction of surface-water flow.

\section{Previous Studies}

The current DFIRM for Gwinnett County was published June 18, 2010 (Federal Emergency Management Agency, 2011). The DFIRM was used to check the inundation extent for stages that are close to the 1-percent and 0.2-percent annual exceedance probability. A HEC-RAS model of Suwanee Creek, which was used in the publication of the DFIRM, was obtained in 2011 from Gwinnett County (Gwinnett County, 2011). The cross sections, stream channel, and bridge details within the study area from the HEC-RAS model were used as a starting point for creation of the model used in this study.

Similar studies that provide flood-inundation maps for a range of stream stages were completed in Albany, Ga., for the Flint River (Musser and Dyar, 2007) and in Atlanta, Ga., for Peachtree Creek (Musser, 2012). The methods for the Flint River model used a finite-element two-dimensional model, which differed from those of the Suwanee Creek model. The methods used for the Peachtree Creek model were similar to those used for the Suwanee Creek model. 


\section{Constructing Water-Surface Profiles}

The water-surface profiles used to produce the 19 flood-inundation maps in this study were computed using HEC-RAS, version 4.1.0 (U.S. Army Corps of Engineers, Hydrologic Engineering Center, 2010). HEC-RAS is a one-dimensional step-backwater model for simulation of water-surface profiles with gradually varied, steady-state (or unsteady-state) flow computation options. For this study, the HEC-RAS analysis was completed by using the steady-state flow computation option.

\section{Hydrologic and Steady-Flow Data}

The hydrologic network in the study area consists of one streamgage on the study reach (fig. 1; table 1). Water level (stage) is measured continuously at this site, and continuous records of streamflow are computed. All watersurface elevations are referenced to North American Vertical Datum of 1988 (NAVD 88). The gage is equipped with a satellite radio transmitter that allows data to be transmitted routinely and made available on the Internet within an hour of collection. Suwanee Creek at Suwanee (02334885) is also equipped with a recording rain gage. Steady-flow data consisted of flow regime, boundary conditions (stage and discharge value), and peak discharge information. Steady-flow data for the study reach were calibrated in the model using the stage-discharge relation at the Suwanee Creek at Suwanee streamgage (02334885).

\section{Topographic/Bathymetric Data}

The cross sections from the HEC-RAS DFIRM model, obtained from Gwinnett County (Gwinnett County, 2011), were used as a starting point for the model used in this study. Hereafter, the term "DFIRM" will be used to describe the model as obtained from Gwinnett County. Additional cross sections were added to the USGS model where the distance between cross sections was more than $500 \mathrm{ft}$ in the DFIRM model. The in-channel elevations of the new cross sections for the USGS model were calculated by extracting the in-channel part of an original cross section and lowering or raising it based on the channel slope between original cross sections. The overbank elevations of the new cross sections for the USGS model were calculated from a raster elevation dataset. The source for the raster elevation was a $5.0-\mathrm{ft}$ by $5.0-\mathrm{ft}$ cell raster from light detection and ranging (LiDAR) data obtained from Gwinnett County. The root-mean-square error (RMSE) of the LiDAR vertical data is about $0.61 \mathrm{ft}$ in bare areas and about $1.21 \mathrm{ft}$ in vegetated areas. The flow lengths between cross sections were recomputed after the new cross sections were added. Additionally, all of the ineffective flow areas were recalculated for all of the cross sections.
Various drainage structures (bridges, culverts, roadway embankments, levees, and dams) in and along the stream affect or have the potential to affect water-surface elevations during floods along the stream. To properly account for these features in the model, structural dimensions for nine bridges were measured and surveyed in the field. The bridge geometry was in the DFIRM HEC-RAS model. Site visits were made to all of the bridges to confirm the accuracy of the bridge geometry. The bridges from upstream to downstream were a footbridge, Lawrenceville Suwanee Road, a footbridge, Martin Farm Road, McGinnis Ferry Road, Buford Highway, Norfolk Southern Railroad, Peachtree Industrial Boulevard, and Noblin Ridge Drive (fig. 2). The upstream footbridge was included in the model, but the downstream footbridge is located just downstream of Lawrenceville Suwanee Road and so would have negligible effect on the streamflow. A detailed description of the methods used to acquire and process the topographic and bathymetric data can be found in Bales and others (2007).

\section{Energy Loss Factors}

Field observations and high-resolution aerial photographs were used to select initial (precalibration) Manning's roughness coefficients (" $n$ " values) for energy (friction) loss calculations. The final Manning's $n$ values ranged from 0.04 to 0.11 for the main channel. The Manning's $n$ values ranged from 0.03 (grass and roads) to 0.18 (forested areas with heavy undergrowth) for the overbank areas modeled in this analysis.

\section{Model Calibration and Performance}

The hydraulic model was calibrated to the most current (2011) stage-discharge relation at the Suwanee Creek at Suwanee streamgage (02334885). No high-water marks were available along Suwanee Creek, so the only calibration point to a water-surface elevation is at the streamgage. The maximum recorded peak discharge was on September 21, 2009, and was 7,870 cubic feet per second $\left(\mathrm{ft}^{3} / \mathrm{s}\right)$ at a stage of about $14.30 \mathrm{ft}$. Though no high-water marks were obtained, the extent of this flood closely matched the $14.5-\mathrm{ft}$ stage in the model at four business locations. At Swift Atlanta, which is located approximately $1 \mathrm{mi}$ upstream of the streamgage, the flood was reported to have reached the top of the curb in their back parking lot. At AES Clean Technology on Martin Farm Road, the flood extent was reported to be approximately $30 \mathrm{ft}$ uphill on the road from a public parking lot on the south side of the road. In the model, the distance is approximately $34 \mathrm{ft}$. At two businesses on the downstream side of Lawrenceville Suwanee Road, Innovative Machining Solutions and Gwinnett Collision, the reported flood extent on their property is close to the 14.5 - $\mathrm{ft}$ stage model. At Gwinnett Collision, the flood came within a few feet of a retaining wall, which matches the model. 
Model calibration in the vicinity of the gage was accomplished by adjusting Manning's $n$ value of the channel until the results of the hydraulic computations closely agreed with the known stage-discharge relation. Differences between measured and simulated water levels for models calibrated to stages were between -0.1 and $+0.1 \mathrm{ft}$ (table 2 ). The boundaries of the DFIRM flood zones were similar to the boundaries of the modeled inundated areas for the 16-ft Suwanee Creek stage in the USGS inundation model. Details on techniques used in model development and calibration can be found in Bales and others (2007).

\section{Development of Water-Surface Profiles}

Profiles were developed for 19 stages at 0.5 - $\mathrm{ft}$ intervals between 7.0 and $16.0 \mathrm{ft}$ as referenced to the Suwanee Creek at Suwanee streamgage (02334885). Discharges corresponding to the various stages were obtained from the most current stagedischarge relation (rating no. 14.1, effective June 2, 2009). Discharges for all profiles were calculated based on a ratio of streamflow to drainage area. Stages and discharge estimates for selected locations and profiles are shown in table 3 .
Table 2. Comparison of hydraulic-model output and watersurface elevations at the Suwanee Creek at Suwanee, Georgia, streamgage (02334885).

[Values listed in feet above North American Vertical Datum of 1988]

\begin{tabular}{|cccc|}
\hline Stage & $\begin{array}{c}\text { Actual water- } \\
\text { surface } \\
\text { elevations }\end{array}$ & $\begin{array}{c}\text { Modeled } \\
\text { water-surface } \\
\text { elevations }\end{array}$ & $\begin{array}{c}\text { Elevation } \\
\text { difference }\end{array}$ \\
\hline 7.0 & 916.9 & 917.0 & +0.1 \\
\hline 7.5 & 917.4 & 917.4 & 0.0 \\
\hline 8.0 & 917.9 & 917.8 & -0.1 \\
\hline 8.5 & 918.4 & 918.4 & 0.0 \\
\hline 9.0 & 918.9 & 918.8 & -0.1 \\
\hline 9.5 & 919.4 & 919.4 & 0.0 \\
\hline 10.0 & 919.9 & 919.8 & -0.1 \\
\hline 10.5 & 920.4 & 920.3 & -0.1 \\
\hline 11.0 & 920.9 & 920.8 & -0.1 \\
\hline 11.5 & 921.4 & 921.4 & 0.0 \\
\hline 12.0 & 921.9 & 921.8 & -0.1 \\
\hline 12.5 & 922.4 & 922.4 & 0.0 \\
\hline 13.0 & 922.9 & 922.9 & 0.0 \\
\hline 13.5 & 923.4 & 923.4 & 0.0 \\
\hline 14.0 & 923.9 & 923.8 & -0.1 \\
\hline 14.5 & 924.4 & 924.3 & -0.1 \\
\hline 15.0 & 924.9 & 925.0 & +0.1 \\
\hline 15.5 & 925.4 & 925.5 & +0.1 \\
\hline 16.0 & 925.9 & 925.8 & -0.1 \\
\hline
\end{tabular}

Table 3. Stages (and water-surface elevations) with corresponding discharge estimates for selected simulated water-surface profiles at selected locations for the Suwanee Creek at Suwanee, Georgia, streamgage (02334885).

[Values 7.0-16.0 represent stage, in feet above gage datum. Values in parentheses (916.9-925.9) represent water-surface elevations, in feet above North American Vertical Datum of 1988]

\begin{tabular}{|c|c|c|c|c|c|c|c|c|c|c|}
\hline Location & \multicolumn{10}{|c|}{ Stage (and water-surface elevations) and discharge estimates } \\
\hline \multicolumn{11}{|c|}{ Stage (and water-surface elevations), in feet } \\
\hline $\begin{array}{l}\text { Suwanee Creek at } \\
\text { Suwanee, Georgia }\end{array}$ & $\begin{array}{c}7.0 \\
(916.9) \\
\end{array}$ & $\begin{array}{c}8.0 \\
(917.9) \\
\end{array}$ & $\begin{array}{c}9.0 \\
(918.9) \\
\end{array}$ & $\begin{array}{c}10.0 \\
(919.9)\end{array}$ & $\begin{array}{c}11.0 \\
(920.9)\end{array}$ & $\begin{array}{c}12.0 \\
(921.9)\end{array}$ & $\begin{array}{c}13.0 \\
(922.9)\end{array}$ & $\begin{array}{c}14.0 \\
(923.9)\end{array}$ & $\begin{array}{c}15.0 \\
(924.9)\end{array}$ & $\begin{array}{c}16.0 \\
(925.9) \\
\end{array}$ \\
\hline \multicolumn{11}{|c|}{ Discharge, in cubic feet per second } \\
\hline Below Ivy Creek & 647 & 850 & 1,250 & 1,830 & 2,560 & 3,480 & 4,600 & 5,920 & 7,450 & 9,150 \\
\hline $\begin{array}{l}\text { Below unnamed tributary } \\
\text { upstream of McGinnis } \\
\text { Ferry Road }\end{array}$ & 725 & 952 & 1,410 & 2,050 & 2,870 & 3,900 & 5,150 & 6,640 & 8,340 & 10,200 \\
\hline
\end{tabular}




\section{Inundation Mapping}

Flood-inundation maps were created based on the Suwanee Creek at Suwanee streamgage (02334885), which has been designated as a NWS flood-forecast point (SWEG1). The maps were created in a GIS by combining the watersurface profiles and digital elevation model data. The digital elevation model data are from a $5.0-\mathrm{ft}$ by $5.0-\mathrm{ft}$ cell raster derived from LiDAR data obtained from Gwinnett County. Estimated flood-inundation boundaries for each simulated profile were developed with HEC-GeoRAS software (U.S. Army Corps of Engineers, Hydrologic Engineering Center, 2009). HEC-GeoRAS is a set of procedures, tools, and utilities for processing geospatial data in ArcGIS (Esri, 2010) by using a graphical user interface (Whitehead and Ostheimer, 2009). The interface allows the preparation of geometric data for import into HEC-RAS and processes simulation results exported from HEC-RAS (U.S. Army Corps of Engineers, Hydrologic Engineering Center, 2010). HEC-GeoRAS results were modified to ensure a hydraulically reasonable transition of the boundary between modeled cross sections relative to the contour data for the land surface (Whitehead and Ostheimer, 2009). The resulting inundation maps have a vertical accuracy of about $0.5 \mathrm{ft}$. The maps show estimated flood-inundated areas overlain on high-resolution, georeferenced, aerial photographs of the study area for each of the water-surface profiles that were generated by the hydraulic model. The bed slope of Suwanee Creek is fairly consistent along the 6.9-mi modeled reach. The sheet numbers corresponding to each 0.5 -ft stage increment at the Suwanee Creek streamgage are shown in table 4.

\section{Suwanee Creek, Georgia, Flood-Inundation Maps on the Internet}

A USGS Flood Inundation Mapping Science World Wide Web portal (http://water.usgs.gov/osw/flood_inundation/) has been established by the USGS to provide estimated floodinundation information to the public. The maps from this study are available in several commonly used electronic file formats that can be downloaded from that portal. Each stream reach displayed on the Web site contains links to the USGS National Water Information System graphs of the current stage and streamflow at the USGS Suwanee Creek at Suwanee streamgage (02334885), to which the inundation maps are referenced. A link also is provided to the NWS AHPS Web site (http://water.weather.gov/ahps/) so that the user can obtain applicable information on forecasted peak stage. The estimated flood-inundation maps are displayed in sufficient detail to note the extent of flooding with respect to individual structures so that preparations for flooding and decisions for emergency response can be performed efficiently.

\section{Disclaimer for Flood-Inundation Maps}

Inundated areas shown should not be used for navigation, regulatory, permitting, or other legal purposes. The USGS provides these maps "as-is" for a quick reference, emergency planning tool but assumes no legal liability or responsibility resulting from the use of this information.

\section{Uncertainties and Limitations Regarding Use of Flood-Inundation Maps}

Although the flood-inundation maps represent the boundaries of inundated areas with a distinct line, some uncertainty is associated with these maps. The flood boundaries shown were estimated based on water stage and discharge at the Suwanee Creek at Suwanee, Ga. (02334885) streamgage. Water-surface elevations along the stream reaches were estimated by steady-state hydraulic modeling, assuming unobstructed flow, and by using streamflows and hydrologic conditions anticipated at the USGS streamgage.

Table 4. Stream stages (and water-surface elevations) at the Suwanee Creek at Suwanee, Georgia, streamgage (02334885), with reference to corresponding map-sheet numbers in this report.

[Values 7.0-16.0 represent stage, in feet above gage datum. Values in parentheses (916.9-925.9) represent water-surface elevation in feet above North American Vertical Datum of 1988]

\begin{tabular}{|c|c|c|c|c|c|c|c|c|c|c|}
\hline \multicolumn{11}{|c|}{ Suwanee Creek at Suwanee } \\
\hline Sheet number & 1 & 2 & 3 & 4 & 5 & 6 & 7 & 8 & 9 & 10 \\
\hline $\begin{array}{l}\text { Stage (water- } \\
\text { surface } \\
\text { elevation) }\end{array}$ & $\begin{array}{c}12.0 \\
(921.9)\end{array}$ & $\begin{array}{c}12.5 \\
(922.4)\end{array}$ & $\begin{array}{c}13.0 \\
(922.9)\end{array}$ & $\begin{array}{c}13.5 \\
(923.4)\end{array}$ & $\begin{array}{c}14.0 \\
(923.9)\end{array}$ & $\begin{array}{c}14.5 \\
(924.4)\end{array}$ & $\begin{array}{c}15.0 \\
(924.9)\end{array}$ & $\begin{array}{c}15.5 \\
(925.4)\end{array}$ & $\begin{array}{c}16.0 \\
(925.9)\end{array}$ & \\
\hline Sheet number & 11 & 12 & 13 & 14 & 15 & 16 & 17 & 18 & 19 & \\
\hline
\end{tabular}


The hydraulic model reflects the land-cover characteristics and any bridge, dam, levee, or other hydraulic structures existing as of October 2011. Unique meteorological factors (timing and distribution of precipitation) may cause actual streamflows along the modeled reach to vary from those assumed during a flood, which may lead to deviations in the water-surface elevations and inundation boundaries shown. Additional areas may be flooded due to unanticipated conditions such as changes in the streambed elevation or roughness, backwater into major tributaries along a main stem river, or backwater from localized debris or ice jams. The accuracy of the floodwater extent portrayed on these maps will vary with the accuracy of the digital elevation model used to simulate the land surface. Additional uncertainties and limitations pertinent to this study are described elsewhere in this report.

If this series of flood-inundation maps will be used in conjunction with National Weather Service (NWS) river forecasts, the user should be aware of additional uncertainties that may be inherent or factored into NWS forecast procedures. The NWS uses forecast models to estimate the quantity and timing of water flowing through selected stream reaches in the United States. These forecast models (1) estimate the amount of runoff generated by precipitation and snowmelt, (2) simulate the movement of floodwater as it proceeds downstream, and (3) predict the flow and stage (and watersurface elevation) for the stream at a given location (AHPS forecast point) throughout the forecast period (every 6 hours and 3 to 5 days out in many locations). For more information on AHPS forecasts, please see http://water.weather.gov/ahps/ pcpn_and_river_forecasting.pdf.

\section{Summary}

A series of estimated flood-inundation maps were developed by the U.S. Geological Survey (USGS), in cooperation with Gwinnett County, Georgia, for a 6.9-mile reach of Suwanee Creek from 440 feet above the confluence with Ivy Creek to about 930 feet below the Noblin Ridge Drive bridge. These maps, available at a USGS Web portal, in conjunction with the real-time stage data from the USGS streamgage at Suwanee Creek at Suwanee, Georgia (02334885), and National Weather Service flood-stage forecasts, can help to guide the general public in taking individual safety precautions and can provide local officials with a tool to efficiently manage emergency flood operations and flood-mitigation efforts.

The maps were developed using the U.S. Army Corps of Engineers HEC-RAS and HEC-GeoRAS computer programs to compute water-surface profiles and to delineate estimated flood-inundation areas for selected stream stages. The maps show estimated flood-inundation areas overlain on high-resolution, georeferenced, aerial photographs of the study area for 0.5 -foot increments of stream stage between 7.0 and 16.0 feet (gage datum) at the Suwanee Creek at Suwanee, Georgia, streamgage (02334885).

\section{References Cited}

Bales, J.D., Wagner, C.R., Tighe, K.C., and Terziotti, Silvia, 2007, LiDAR-derived flood-inundation maps for realtime flood-mapping applications, Tar River Basin, North Carolina: U.S. Geological Survey Scientific Investigations Report 2007-5032, 42 p.

Clark, W.Z., Jr., and Zisa, A.C., 1976, Physiographic map of Georgia: Georgia Geologic Survey, scale 1:2,000,000.

Esri [2010], ArcGIS Desktop: Version 9.3.1: Accessed

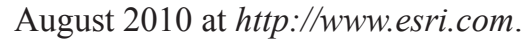

Federal Emergency Management Agency [2011], Digital Flood Insurance Rate Map: Accessed March 2011 at http://www.msc.fema.gov.

Fry, J.A., Xian, G., Jin, S., Dewitz, J.A., Homer, C.G., Yang, L., Barnes, C.A., Herold, N.D., and Wickham, J.D., 2011, Completion of the 2006 National Land Cover Database for the conterminous United States: Photogrammetric Engineering \& Remote Sensing, v. 77, no. 9, p. 858-864.

Gwinnett County [2011], Flood Information Portal: Accessed April 2011 at http://www.gwinnettfloodplain.com/gwinnett/ welcome.htm.

Musser, J.W., 2012, Flood-inundation maps for Peachtree Creek from the Norfolk Southern Railway bridge to the Moores Mill Road NW bridge, Atlanta, Georgia: U.S. Geological Survey Scientific Investigations Map 3189, 9 p., 50 sheets, available online at http://pubs.usgs.gov/ $\operatorname{sim} / 3189 /$.

Musser, J.W., and Dyar, T.R., 2007, Two-dimensional flood-inundation model of the Flint River at Albany, Georgia: U.S. Geological Survey Scientific Investigations Report 2007-5107, 49 p., available online at http://pubs. usgs.gov/sir/2007/5107/.

U.S. Army Corps of Engineers, Hydrologic Engineering Center, 2009, HEC-GeoRAS, GIS Tools for Support of HEC-RAS using ArcGIS: User's Manual, version 4.2 [variously paged].

U.S. Army Corps of Engineers, Hydrologic Engineering Center, 2010, HEC-RAS River Analysis System: Hydraulic Reference Manual, version 4.1 [variously paged].

U.S. Census Bureau [2012], State and County QuickFacts: Accessed January 2012 at http://quickfacts.census.gov/ qfd/index.html.

Whitehead, M.T., and Ostheimer, C.J., 2009, Development of a flood-warning system and flood-inundation mapping for the Blanchard River in Findlay, Ohio: U.S. Geological Survey Scientific Investigations Report 2008-5234, 9 p. 
Manuscript approved on July 25, 2012

Edited by Kimberly A. Waltenbaugh Illustrations and layout by Caryl J. Wipperfurth

Science Publishing Network, Raleigh PSC

For more information about this publication, contact: USGS Georgia Water Science Center

3039 Amwiler Road

Atlanta, GA 30360

telephone: $770-903-9100$

http://ga.water.usgs.gov/ 
